\title{
STUDENTS' MATHEMATICAL THINKING SKILL VIEWED FROM CURIOSITY THROUGH PROBLEM- BASED LEARNING MODEL ON INTEGRAL CALCULUS
}

\author{
Zetriuslita*, Rezi Ariawan \\ Universitas Islam Riau, Indonesia
}

\begin{tabular}{l} 
Article Info \\
\hline Article history: \\
Received Apr 25, 2020 \\
Revised Sep 22, 2020 \\
Accepted Sep 23, 2020 \\
\hline
\end{tabular}

\section{Keywords:}

Curiosity,

Integral Calculus,

Mathematical Critical Thinking,

Problem-Based Learning,

Teaching Material

\begin{abstract}
This study aims to find out the improvement of students' mathematical critical thinking viewed from curiosity through teaching materials with Problem Based Learning model. This is quasi-experimental research. The samples are, where the overall population consists of 75 samples divided into two classes. This research employed a simple random sampling technique. The instruments were the mathematical critical thinking skill test and curiosity questionnaire. The technique of data collection was carried out with test and non-test techniques. The data were analyzed through a two-way Anova test. Based on the analysis and interpretation of the research findings, it was found that: there was an improvement in students' mathematical critical thinking skill from High curiosity by using teaching materials with Problem Based Learning model; 1) There was an improvement from Average curiosity through learning with Integral Calculus teaching materials; 2) There was an improvement from Low curiosity; 3) There was no improvement from the level of curiosity (High, Medium, Low) through Problem-based Learning. 4) There was no influence between the level of curiosity and learning in improving students' mathematical critical thinking skills. Do more in-depth studies related to improving mathematical critical thinking skills by reviewing other affective aspects
\end{abstract}

Copyright (C) 2021 IKIP Siliwangi. All rights reserved.

\section{Corresponding Author:}

Zetriuslita,

Department of Mathematics Education,

Universitas Islam Riau,

Jl. Kaharuddin Nasution No.113, Bukit Raya, Pekanbaru, Riau 28284, Indonesia.

Email: zetriuslita@edu.uir.ac.id

\section{How to Cite:}

Zetriuslita, Z., \& Ariawan, R. (2021). Students' mathematical thinking skill viewed from curiosity through problem-based learning model on integral calculus. Infinity, 10(1), 31-40.

\section{INTRODUCTION}

Calculus is a course that nearly exists in every university, especially in Mathematics and Science majors. It is also one of the compulsory courses and skills for students majoring in Science, especially in Mathematics. They are expected to excel in this important subject. As a result, some researchers have carried out a research to evaluate and improve students' ability in learning Calculus (Hartono \& Noto, 2017; Lumbantoruan, 2017; Mutakin, 2013; Parma \& Saparwadi, 2015; Ramdani, 2012; Romadiastri, 2013; Sopiany \& Rikayanti, 2018; Usman et al., 2015). 
Furthermore, the researcher has also conceived her own studies related to Calculus, namely: An Analysis of Students' Mathematical Critical Thinking, connecting on Integral Calculus Problem Solving based on the students' academic level, gender, cognitive style (Ariawan \& Nufus, 2017; Zetriuslita et al., 2016a; 2016b). Practicality teaching material based on the problem based learning to improve mathematical critical thinking ability (Zetriuslita \& Ariawan, 2016).

Based on the previous studies, the researcher focused on mathematical critical thinking ability. Critical thinking ability is quite necessary in Calculus. Klurik and Rudnick (Zetriuslita et al., 2018) argued that critical thinking in mathematics involves testing, questioning, connecting, evaluating all aspects in any situations or problems. It doesn't only demand knowledge and comprehension but also more than that. The given problem consists of analytical ability. Ennis (2011) stated that critical thinking is a summary of logical thinking (Logic) and reflective which emphasizes on decision making about what we believe or do. According to Johnson (2007), it's a focused and clear process which is employed in mental activities such as problem solving, decision making, persuasion, assumption analysis, and conducting scientific research. In line with the statement, Ennis (2011) mentioned that the aspects of critical thinking are focus, reasons, inference, situation, clarity, and overview.

From the statements above, it indicates that critical thinking can make and train someone to do math. Students don't learn mathematical rules or formulas by heart but learn mathematics by action and active discovery. Consequently, critical thinking is very important to develop. In general, developing critical thinking or improving mathematics learning outcome can be achieved by using teaching materials or learning media (Bien et al., 2019; Dewi, 2016; Guntur et al., 2017; Hikmawati et al., 2013; Melisa, 2014; Putra et al., 2017; Saparwadi \& Yuwono, 2019).

Based on the researcher's teaching experience, there was a problem related to the lack of determination and curiosity. It was seen from the students' unwillingness to find out the answers to the given problems, especially in Calculus Integral subject. They didn't try to ask the teacher about the problem they didn't understand. This level of curiosity can affect the students' activity in learning and also lead to their comprehension. Carin (1997) defined curiosity as one's willingness and need to obtain answers from a question or things that spark curiosity. Curiosity can foster internal motivation for learning and understanding something, therefore it can be developed in the learning process (Ameliah \& Munawaroh, 2016; Mardhiyana, 2017; Nurkamilah, 2017; Solehuzain \& Dwidayanti, 2017). In accordance with the findings, the researcher did some studies in regards to students' mathematical curiosity (Zetriuslita et al., 2017).

From the review of related literature and identification of the problem above, students' curiosity is a cognitive aspect that seeks attention and serious consideration. Subsequently, the researcher's interest focuses on improving students' mathematical critical thinking ability viewed from curiosity. The researcher applied teaching materials based on Problem Based learning.

The researcher suggested the following hypotheses, such as: (1) There is a significant difference in terms of High Curiosity between students who use Calculus Integral teaching materials based on Problem-Based Learning model and those who follow conventional learning; (2) There is a significant difference in terms of Medium Curiosity between students who use Calculus Integral teaching materials based on Problem-Based Learning model and those who follow conventional learning; (3) There is a significant difference in terms of Low Curiosity between students who use Calculus Integral teaching materials based on ProblemBased Learning model and those who follow conventional learning; (4) There is a significant difference in terms of Curiosity (High, Medium, Low) between students who used Calculus Integral teaching materials based on Problem- Based Learning model and those who follow 
conventional learning; and (5) There is an interaction effect between level of curiosity and learning towards the improvement of mathematical critical thinking ability.

\section{METHOD}

This study is a quantitative research. Quantitative research is the process of using data in numerical form as a means to find out knowledge (Creswell \& Creswell, 2017; Sugiyono, 2011). The type of research is quasi-experimental research with Pre-test and Posttest Non-Equivalent Group Design described in Table 1.

Table 1. Pre-test and post-test non-equivalent group design (Cohen et al., 2007)

\begin{tabular}{cccc}
\hline & Pre-test & Treatment & Posttest \\
\hline Experiment & $\mathrm{O}_{1}$ & $\mathrm{X}$ & $\mathrm{O}_{2}$ \\
Control & $\mathrm{O}_{1}$ & - & $\mathrm{O}_{2}$ \\
\hline
\end{tabular}

Description:

$\mathrm{O}_{1} \quad$ : Pretest of experiment classes and control classes

$\mathrm{O}_{2} \quad$ : Postest of experiment classes and control classes

$\mathrm{X} \quad$ : Treatment using integral calculus-based teaching materials problem based learning

- $\quad$ : Treatment with does not use teaching materials problem-based integral Calculus

The samples of this research were the $2^{\text {nd }}$ semester students of Mathematics Education FKIP UIR who took Integral Calculus subject. There were two classes. Saturated sampling was used because the samples were selected from the overall population by using simple random sampling technique. The lottery showed that $2 \mathrm{~A}$ was chosen as the control class (conventional learning) and $2 \mathrm{~B}$ as the experiment class (using Calculus Integral teaching materials with Problem-Based Learning model). This research was conducted in the even semester of Academic Year 2018/2019.

The instruments of this research consisted of mathematical critical thinking ability worksheet and curiosity questionnaire. The data collection was carried out by using both instruments for test and non-test technique respectively. The test about critical thinking ability was given in the first and last meeting, while the questionnaire of curiosity was distributed in the first meeting only. The data obtained from the test and questionnaire was analyzed by using descriptive statistics and inferential statistics with SPSS version 22 software. In order to determine the level of curiosity, the researcher used the following interval in Table 2.

Table 2. Interval group level of curiosity (Zetriuslita et al., 2016b)

\begin{tabular}{cc}
\hline Group Level of Curiosity & Interval \\
\hline High & $x \geq \bar{x}+\sigma$ \\
Medium & $\bar{x}+\sigma<x<\bar{x}+\sigma$ \\
Low & $x \leq \bar{x}-\sigma$ \\
\hline
\end{tabular}

Description:

$\mathrm{x}=$ students' curiosity score

$\bar{x}=$ mean score of students' curiosity

$\sigma=$ Standard deviation of students' curiosity score 
Meanwhile, the improvement of mathematical ability intended is normalized gain obtained from the pre-test and post-test results, with the following formula by Meltzer (2002).

$$
N_{\text {Gain }}=\frac{\text { Postest }- \text { Pretest }}{\text { Ideal Score }- \text { Pretest }}
$$

In order to the test hypothesis of the research, t-test, one-way anova test and two-way anova test were used.

\section{RESULTS AND DISCUSSION}

\subsection{Results}

The data analysis of improving mathematical critical thinking ability was obtained from N-Gain result. It was classified into the level of curiosity, starting from grouping the students based on their curiosity level. From the result of curiosity score, the data were obtained as follows: The data of improving mathematical critical thinking ability viewed from Curiosity is presented in Table 3.

Table 3. Description of students' total in terms of curiosity

\begin{tabular}{ccc}
\hline \multirow{2}{*}{ Level of Curiosity } & \multicolumn{2}{c}{ Learning } \\
\cline { 2 - 3 } & PMBAKIPBL & PTMBAKIPBL \\
\hline High & 5 & 5 \\
& $(13.16 \%)$ & $(13.5 \%)$ \\
Medium & 26 & 27 \\
& $(68.42 \%)$ & $(72.97 \%)$ \\
Low & 7 & 5 \\
\multirow{2}{*}{ Total } & $(18.42 \%)$ & $(13.51 \%)$ \\
& 38 & 37 \\
\end{tabular}

Description:

PMBAKIPBL : Learning using integral calculus teaching materials based on problembased learning

PTMBAKIPBL: Learning does not use integral calculus teaching materials based on problem-based learning

Table 3 shown that in experimental class is better than control class. Students in the experimental class and the control class with Curiosity were not significantly different from the level of curiosity. This indicates that the curiosity of the experimental class and control class students is almost the same. Basically, if the curiosity is not much different, then the resulting mathematics learning outcomes should not be different either. However, with different treatment with the use of problem-based learning materials, the learning outcomes can be presented in the following table. By using SPSS Version22, the calculation of hypotheses 1,2, and 3 are presented in the Table 4. 
Table 4. The improvement of mathematical critical thinking

\begin{tabular}{ccc}
\hline Level of Curiosity & \multicolumn{1}{c}{ Statistics (T-Test) } & Conclusion \\
\hline High & Sig. (2-tailed) $=0.000<0,05$ & Hypothesis is accepted \\
Medium & Sig. (2-tailed) $=0.000<0.05$ & Hypothesis is accepted \\
Low & Sig. (2-tailed) $=0.000 \leq 0.05$ & Hypothesis is accepted \\
\hline
\end{tabular}

Table 4 show that on average the improvement of students' mathematical critical thinking ability from high level of curiosity, medium and low who followed Problem Based learning is better than studentswho follow conventional learning. Then, hypothesis was tested by using one-way Anova test (Table 5).

Table 5. One-ANOVA Test of improvement critical thinking based on curiosity

\begin{tabular}{cccccc}
\hline & Sum of Squares & Df & Mean Square & F & Sig. \\
\hline Between Groups & 0.003 & 2 & 0.002 & & \\
Within Groups & 2.287 & 72 & 0.032 & 0.50 & 0.952 \\
Total & 2.290 & 74 & & & \\
\hline
\end{tabular}

From Table 5, it was obtained the $\operatorname{Sig}=0,952 \geq \alpha$, with $\alpha=0,05$. It means $\mathrm{H}_{0}$ is accepted and $\mathrm{H}_{1}$ is rejected. When $\mathrm{H}_{1}$ is rejected, the hypothesis "There is a significant difference of improving mathematical critical thinking ability between students from curiosity level who follow Problem Based learning and conventional learning" is rejected. In other words, there is no significant difference of improving the students' critical thinking ability viewed from level of curiosity.

Next, hypothesis 5 was tested by using two-way Anova test with the SPSS Version 22 software. The result was obtained as follows in Table 6.

Table 6. Two-Way ANOVA Test

\begin{tabular}{cccccc}
\hline Source & $\begin{array}{c}\text { Type III Sum of } \\
\text { Square }\end{array}$ & Df & $\begin{array}{c}\text { Mean } \\
\text { Square }\end{array}$ & F & Sig. \\
\hline Corrected Model & $1.271^{\mathrm{a}}$ & 5 & 0.254 & 17.204 & 0.000 \\
Intercept & 9.226 & 1 & 9.226 & 624.620 & 0.000 \\
CURIOSITY & 0.001 & 2 & 0.000 & 0.021 & 0.980 \\
KELAS & 0.949 & 1 & 0.949 & 64.239 & 0.000 \\
CURIOSITY*KELAS & 0.067 & 2 & 0.033 & 2.263 & 0.112 \\
Error & 1.019 & 69 & 0.015 & & \\
Total & 18.307 & 75 & & & \\
Corrected Total & 2.290 & 74 & & & \\
\hline
\end{tabular}

Table 6 show that Sig. $=0.112>0.05$, where hypothesis $\mathrm{H}_{1}$ is rejected, meaning there is no interaction effect between level of curiosity and learning towards the improvement of mathematical critical thinking ability. The curiosity has no significant effect on the improvement, it's indicated with Sig. $=0.980>0.05$ (Table 6), meanwhile the class or in this case learning has a significant effect on the improvement shown by Sig $=0.000<0.05$. 


\subsection{Discussion}

The result of inferential statistics show that the improvement of mathematical critical thinking ability for the students who follow Problem based learning in Integral Calculus is higher than those who follow conventional learning. It means that the use of Integral calculus teaching materials with Problem Based learning is effective in improving students' mathematical critical learning ability. This is in line with a research finding by Guntur et al. (2017) which stated that the effect between intensively, rarely, and never using comics towards students' self- learning. Dewi (2016) said that the average rank of experimental group is higher than that of control group. In other words, students' learning outcome in learning with Screencast-o-matic media is better than students who follow conventional learning. So this research reinforce the assumption that using screencast- o-matic is effective to increase students' learning outcome in Integral Calculus subject. Hikmawati et al. (2013) stated that there was an influence of the use of instructional media and cognitive styles on mathematics learning outcomes of Grade VIII Madrasah Tsanawiyah students and there was no interaction between the use of instructional media and cognitive style on mathematics learning outcomes of Grade VIII Madrasah Tsanawiyah students.

Bien et al. (2019) stated that the use of teaching calculus textbooks was effective in increasing the ability to understand student concepts. Farhan and Retnawati (2014) stated that PBL can make students more active when they are working on Worksheets based on PBL made by teachers. Gordah and Fadillah (2014) stated that increasing students' mathematical representation ability through the use of differential calculus teaching materials based on the open ended approach was classified as moderate, there was no difference in increasing students' mathematical representation ability in terms of gender (male and female); 3) there is a difference in the improvement of students 'mathematical representation ability in terms of the initial level of students' ability (upper, middle, and lower).

Meanwhile, if viewed based on the level of curiosity, thenthere is no difference in the increase in mathematical critical thinking ability reviewed based on curiosity (high, medium, low) between students who learn by using integral calculus based on problem based learning with those not. Furthermore, there is also no interaction effect between learning and curiosity on the improvement of mathematical critical thinking ability. There are several analyzes that researchers can convey why there are no differences in enhancement and interaction, including: (1) the questionnaire researchers do before curiosity study or research is carried out, with the aim only to determine the condition of student curiosity. Even though if the questionnaire was given after they learned by using integral calculus based learning materials based on problem based learning, maybe their curiosity would be better; (2) The structure of teaching materials is designed to improve critical thinking ability, so that attention to students' curiosity lacks attention. The results of this study are in line with research conducted by Zetriuslita et al. (2017) which states that after being given treatment, mathematical curiosity of students does not/ experience a significant increase. This is due in the learning process, lecturers are not maximized in developing students' mathematical curiosity, and other factors are the lack of maximum learning tools for student worksheets or LKM. Furthermore Solehuzain and Dwidayati (2017) stated that there was a significant influence between curiosity on students' mathematical creative thinking abilities on the problem based learning model of learning with open-ended problems. The variable of curiosity affects the variable of mathematical creative thinking ability by $77.4 \%$ and the rest is influenced by other factors. 


\section{CONCLUSION}

The conclusion of this research are: (1) Improvement of mathematical critical thinking ability of students who learn to use integral calculus based problem based learning is better than improvement in mathematical critical thinking ability of students who learn not to use integral based learning calculus based on problem based learning both in terms of high, medium, high curiosity levels low; (2) There is no increase in mathematical critical thinking ability of students who learn to use integral based learning calculus based on problem based learning compared to the students who learn not to use integral based learning calculus based on problem based learning based on curiosity (high, medium, low ); (3) There is no effect of interaction between levels of curiosity and learning on improving students' mathematical critical thinking ability.

There are a number of things that researchers can advise on the results of this study, namely: It is recommended that a more in-depth study is conducted related to improving mathematical critical thinking skills by reviewing other affective aspects, a study in the form of further development of calculus root material which is not only based on active learning models, but by using the help of mathematical software such as matlab, geogebra and others. Studies are more extended, not only focus on integral calculus, but focus on the study of calculus (differential calculus, and calculus of many variables or advanced calculus). Future studies must use a comprehensive research method in the form of a mix method, which combines data obtained qualitatively with data obtained quantitatively.

\section{ACKNOWLEDGMENTS}

The author would like to thank Universitas Islam Riau for the support in funding and the research team for their commitment in this research.

\section{REFERENCES}

Ameliah, I. H. (2016). Pengaruh keingintahuan dan rasa percaya diri siswa terhadap hasil belajar matematika kelas VII MTs Negeri I Kota Cirebon. Eduma: Mathematics Education Learning and Teaching, 5(1), 9-21. https://doi.org/10.24235/eduma.v5i1.598

Ariawan, R., \& Nufus, H. (2017). Profil kemampuan koneksi matematis mahasiswa dalam menyelesaikan masalah pada mata kuliah Kalkulus 1 Ditinjau Berdasarkan Gaya Kognitif. Suska Journal of Mathematics Education, 3(2), 102-110. https://doi.org/10.24014/sjme.v3i2.4036

Bien, Y. I., Daniel, F., \& Taneo, P. N. (2019). Pengembangan buku ajar kalkulus integral berbasis maple untuk meningkatkan pemahaman konsep mahasiswa. ANARGYA: Jurnal Ilmiah Pendidikan Matematika,2(1), 39-45. https://doi.org/10.24176/anargya.v2i1.3404

Carin, A. (1997). Teaching Modern Science. New Jersey: Pretice-Hall.

Cohen, L., Manion, L., \& Morrison, K. (2007). Research Methods in Education (sixth). New York: Routledge Taylor \& Francis Group.

Creswell, J. W., \& Creswell, J. D. (2017). Research design: Qualitative, quantitative, and mixed methods approaches. Sage publications. 
Dewi, S. V. (2016). Efektivitas penggunaan media Screencast O-Matic pada mata kuliah kalkulus integral terhadap hasil belajar mahasiswa. JP3M (Jurnal Penelitian Pendidikan dan Pengajaran Matematika), 2(1), 61-66.

Ennis, R. (2011). Critical thinking: Reflection and perspective Part II. Inquiry: Critical thinking across the Disciplines, 26(2), 5-19. https://doi.org/10.5840/inquiryctnews201126215

Farhan, M., \& Retnawati, H. (2014). Keefektifan PBL dan IBL ditinjau dari prestasi belajar, kemampuan representasi matematis, dan motivasi belajar. Jurnal Riset Pendidikan Matematika, 1(2), 227-240. https://doi.org/10.21831/jrpm.v1i2.2678

Gordah, E. K., \& Fadillah, S. (2014). Pengaruh Penggunaan Bahan Ajar Kalkulus Diferensial Berbasis Pendekatan Open Ended Terhadap Kemampuan Representasi Matematis Mahasiswa. Jurnal pendidikan dan kebudayaan, 20(3), 340-352. https://doi.org/10.24832/jpnk.v20i3.148

Guntur, M., Muchyidin, A., \& Winarso, W. (2017). Pengaruh penggunaan bahan ajar matematika bersuplemen komik terhadap kemandirian belajar siswa. Eduma: Mathematics Education Learning and Teaching, 6(1), 43-51. https://doi.org/10.24235/eduma.v6i1.1667

Hartono, W., \& Noto, M. S. (2017). Pengembangan modul berbasis penemuan terbimbing untuk meningkatkan kemampuan matematis pada perkuliahan kalkulus integral. JNPM (Jurnal Nasional Pendidikan Matematika), 1(2), 320-333. https://doi.org/10.33603/jnpm.v1i2.616

Hikmawati, H., Kamid, K., \& Syamsurizal, S. (2013). Pengaruh penggunaan media pembelajaran dan gaya kognitif terhadap hasil belajar matematika siswa kelas VIII madrasah tsanawiyah. Jurnal Tekno-pedagogi, 3(2), 1-11.

Johnson, E. B. (2007). Contextual teaching and learning: Menjadikan kegiatan belajarmengajar mengasyikkan dan bermakna. (Diterjemahkan oleh A. Chaedar Alwasilah). Mizan Learning Center.

Lumbantoruan, J. H. (2017). Pengembangan bahan ajar integral tak tentu berbasis model small group discussion di program studi pendidikan matematika FKIP UKI tahun 2016/2017. Jurnal Dinamika Pendidikan, 10(2), 99-118.

Mardhiyana, D. (2017). Upaya meningkatkan rasa ingin tahu mahasiswa melalui penerapan pembelajaran berbasis proyek pada mata kuliah evaluasi proses dan hasil pembelajaran matematika. Delta: Jurnal Ilmiah Pendidikan Matematika, 5(1), 1-8. https://doi.org/10.31941/delta.v5i1.389

Melisa, M. (2014). Efektivitas modul berbasis penemuan terbimbing pada perkuliahan kalkulus peubah banyak I. Lemma, 1(1), 26-32.

Meltzer, D. E. (2002). The relationship between mathematics preparation and conceptual learning gains in physics: A possible "hidden variable" in diagnostic pretest scores. American journal of physics, 70(12), 1259-1268. https://doi.org/10.1119/1.1514215

Mutakin, T. Z. (2013). Analisis kesulitan belajar kalkulus 1 mahasiswa teknik informatika. Formatif: Jurnal Ilmiah Pendidikan MIPA, 3(1), 49-60. https://doi.org/10.30998/formatif.v3i1.113

Nurkamilah, M. (2017). Upaya meningkatkan keingintahuan matematis siswa menggunakan guided discovery learning setting kolaboratif (Penelitian tindakan kelas kelas VIII 
SMP Muhammadiyah 3 Depok Sleman Yogyakarta). Jurnal THEOREMS (The Original Research of Mathematics), 1(2), 51-63.

Parma, P., \& Saparwadi, L. (2015). Pengembangan Model Pembelajaran Kalkulus Berbantuan Komputer melalui Program Maple di Program Studi Pendidikan Matematika. Jurnal Elemen, 1(1), 37-48.

Putra, R. S., Wijayati, N., \& Mahatmanti, F. W. (2017). Pengaruh penggunaan media pembelajaran berbasis aplikasi android terhadap hasil belajar siswa. Jurnal Inovasi Pendidikan Kimia, 11(2), 2009-2018.

Ramdani, Y. (2012). Pengembangan instrumen dan bahan ajar untuk meningkatkan kemampuan komunikasi, penalaran, dan koneksi matematis dalam konsep integral. Jurnal Penelitian Pendidikan, 13(1), 44-52.

Romadiastri, Y. (2013). Penerapan pembelajaran kontekstual pada kalkulus 2 bahasan volum benda putar. Jurnal Phenomenon, 3(1), 131-143. https://doi.org/10.21580/phen.2013.3.1.179

Saparwadi, L., \& Yuwono, T. (2019). Pembelajaran kalkulus berbantuan sofware maple: studi perbedaan hasil kerja mahasiswa dengan menggunakan maple dan tanpa menggunakan maple. Jurnal Elemen, 5(1), 23-30.

Solehuzain, S., \& Dwidayati, N. K. (2017). Kemampuan berpikir kreatif dan rasa ingin tahu pada model problem-based learning dengan masalah open ended. Unnes Journal of Mathematics Education Research, 6(1), 103-111.

Sopiany, H. H. N., \& Rikayanti, R. (2018). Mensinergikan kemampuan geometri dan analisis pada mata kuliah kalkulus diferensial melalui bahan ajar berbasis geogebra. Kreano, Jurnal Matematika Kreatif-Inovatif, 9(2), 164-173.

Sugiyono, S. (2011). Metode penelitian pendidikan (Pendekatan kuantitatif, kualitatif, dan $R \& D)$. Bandung: Alfabeta.

Usman, S, R. B., \& Hasbi, M. (2015). Proses berpikir dan respon balikan mahasiswa terhadap pelaksanaan pembelajaran kalkulus integral. Jurnal Peluang, 4(2), 18-29.

Zetriuslita, Z., \& Ariawan, R. (2016). Development of critical thinking ability test mathematical content shaped description on flat field size and volume rotate objects. Proceeding International Seminar on Mathematics, Science, and Computer Education, 38-42.

Zetriuslita, Z., Ariawan, R., \& Nufus, H. (2016a). Students' critical thinking ability: description based on academic level and gender. Journal of Education and Practice, 7(12), 154-164.

Zetriuslita, Z., Ariawan, R., \& Nufus, H. (2016b). Analisis kemampuan berpikir kritis matematis mahasiswa dalam menyelesaikan soal uraian kalkulus integral berdasarkan level kemampuan mahasiswa. Infinity Journal, 5(1), 56-66. https://doi.org/10.22460/infinity.v5i1.p56-66

Zetriuslita, Z., Wahyudin, W., \& Jarnawi, J. (2017). Mathematical critical thinking and curiosity attitude in problem based learning and cognitive conflict strategy: A study in number theory course. International Education Studies, 10(7), 65-78. https://doi.org/10.5539/ies.v10n7p65

Zetriuslita, Z., Wahyudin, W., \& Dahlan, J. A. (2018). Association among mathematical critical thinking skill, communication, and curiosity attitude as the impact of 
problem-based learning and cognitive conflict strategy (PBLCCS) in number theory course. Infinity Journal, 7(1), 15-24. https://doi.org/10.22460/infinity.v7i1.p15-24 